\title{
Brief chronology of the Troubles and origins of the peace process
}

February 1967

October 1968

August 1969

August 1971

January 1972

March 1972

December 1973

May 1974

December 1974

May 1981

October 1981

June 1983

1985

November 1987

January 1988

October 1988

March 1989

November 1989
Formation of the Northern Ireland Civil Rights Association. The Derry Civil Rights March.

Arrival of British troops in Northern Ireland.

The introduction of internment.

Bloody Sunday.

Introduction of direct rule.

Sunningdale Agreement.

Ulster Workers' Council strike.

Provisional IRA (PIRA) declares a ceasefire to conduct talks with British Government.

Republican Bobby Sands dies on hunger strike. Nine other republicans die.

Hunger strikes come to an end.

Sinn Fein obtains 13.4 per cent of the vote in Northern Ireland.

Anglo-Irish Agreement.

PIRA kills eleven people and injures many more at a

Remembrance Sunday service in Enniskillen.

Social Democratic and Labour Party (SDLP) leader John Hume meets Sinn Fein leader Gerry Adams.

British Government imposes broadcasting ban on Sinn Fein and other groups linked to paramilitaries.

Gerry Adams comments on the need for a 'non-armed political movement to work for self-determination'.

Northern Ireland Secretary Peter Brooke states that the PIRA cannot be militarily defeated and that talks could follow an end to violence. 
November 1990 Peter Brooke states that the UK has 'no selfish strategic or economic interest' in Northern Ireland. Brooke goes on to say that 'It is not the aspiration to a sovereign, united Ireland against which we set our face, but its violent expression.'

March 1991 Talks begin, chaired by Peter Brooke. Talks end when the Intergovernmental Conference, which emerged from the Anglo-Irish Agreement, is resumed. The talks focus on Strand One only and the process of talks is constructed along the lines of three strands: relations in Northern Ireland, relations between Northern Ireland and the Republic of Ireland and relations between Dublin and London.

February 1992 Sinn Fein publishes the document Towards a Lasting Peace in Ireland, setting out a political peace strategy.

May 1992

April 1993 Strand Two talks chaired by Patrick Mayhew on North-South relations are launched in Dublin and last until November. The Ulster Unionist Party attends but the Democratic Unionist Party does not.

John Hume and Gerry Adams make a joint statement about Irish people as a whole requiring a right to self-determination. The statement is made after Gerry Adams is seen visiting the home of John Hume in Derry.

October 1993 Ten people are killed when a PIRA bomb explodes in a fish shop on the loyalist Shankill Road.

November 1993 Secret communications between the PIRA and London are revealed.

December 1993 Downing Street Declaration is released stating that Irish unity would require 'double consent' support of majorities in both parts of Ireland and that no constitutional change would occur without the consent of the majority of the people in Northern Ireland.

January 1994 President Clinton agrees a visa for Gerry Adams to visit the United States.

June 1994 Loyalists kill six Catholic men at a bar in Loughinisland, Co. Down.

August 1994 The PIRA announces 'a complete cessation of military activities'.

September 1994 The British Government lifts the broadcasting ban on Sinn Fein. 
October 1994

February 1995

March 1995

May 1995

July 1995

November 1995

January 1996

February 1996

May 1996

June 1996

July 1996

April 1997
The Combined Loyalist Command (an umbrella body for the Ulster Volunteer Force, the Red Hand Commando and the Ulster Defence Association) announces a ceasefire.

British and Irish Governments release the Frameworks Document.

Northern Ireland Secretary Patrick Mayhew reveals a threepoint plan to try to remove PIRA weapons in advance of talks, making decommissioning a key condition for reaching agreement.

Sinn Fein meets British Government Minister Michael Ancram after exploratory dialogue with senior officials.

Drumcree parade becomes flashpoint of the marching season after members of the Orange Order are prevented from marching through a nationalist area.

President Clinton visits Northern Ireland.

The Mitchell Report is published. It canvasses for elections to roundtable talks and stresses a commitment to non-violence as a basis for participation.

The PIRA ends its ceasefire with a bomb in Canary Wharf, London, killing two. Sinn Fein is excluded from talks.

Elections take place to decide participants at talks. Sinn Fein gets 15.5 per cent of the votes but does not take part, having not made the necessary commitment to non-violence. The PIRA ceasefire is not renewed. Talks take place in Castle Buildings, Belfast and are chaired by Senator George Mitchell.

The PIRA plants a bomb in Manchester city centre.

Drumcree creates a stand-off, but police allow marchers to complete the route. This is followed by major rioting. The PIRA creates hoax bomb alerts in the UK, targeting motorways and the Grand National horse race. 